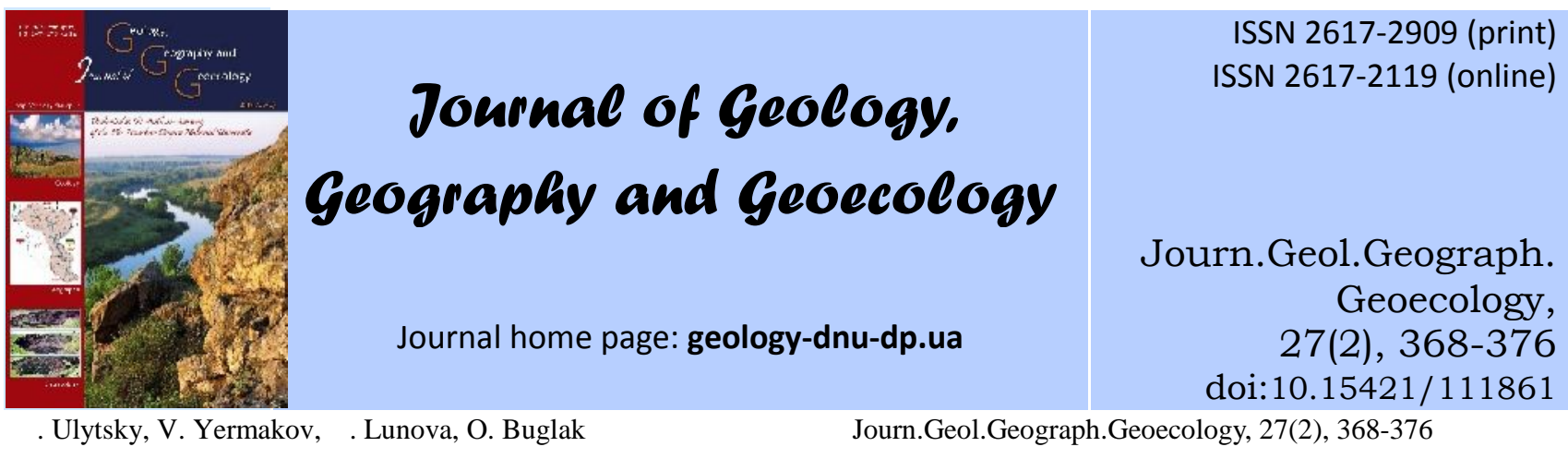

\title{
Environmental risks and assessment of the hydrodynamic situation in the mines of Donetsk and Lugansk regions of Ukraine
}

\author{
. Ulytsky, V. Yermakov, . Lunova, O. Buglak
}

State ecology academy of postgraduate education and management, Kyiv e-mail: Oksanalunova@gmail.com

Received 20.07.2018;

Received in revised form 04.09.2018; Accepted 19.09.2018

Abstract. Modern environmental risks and threats relate with the negative impact of anthropogenic and natural factors on ecosystems, man-caused negative impact of industrial and potentially hazardous objects, pollution of drinking water sources, agricultural land, atmospheric air, deviation of the geological environment and subsoil on the safety of life in certain areas. Coal enterprises are one of the objects of high ecological danger and critical infrastructure. Today, environmental safety in the east of Ukraine should be considered in close connection with the ecological and man-made threats associated with combat operations in these territories. The authors carried out an analysis of scientific researches of past years and provided an assessment of environmental risks in the territories of coal mining enterprises in the present conditions considering the structural-geological, geofiltration and mining-geological parameters typically for the Donetsk and Luhansk regions of Ukraine. The article considers the location of mines in Donetsk and Lugansk regions as zones of high ecological danger. The existing ecological threats and risks are determined, recommendations for minimization threats and risks in case of anthropogenic and environmental disasters are provided. The equation of calculating the coefficient of filtration in rocks is made, mineral-technical parameters of coal mines are analyzed. It is shown that one of the most probable factors of the transition of the territory into a zone of an emergency situation of a regional scale is the emergence of real threats to the life of a large number of people in the conditions of mass flooding of mines due to the termination of power supply of drainage and ventilation systems. Also in the article scientifically substantiated the provision of an acceptable level of environmental safety of the constituent parts of the environment (water environment) for the population living within the mining and agglomeration, taking into account the environmental factors of the negative factor-forming factors, as well as forecasting the hydrodynamic situation.

Key words:ecological safety, threats and risks, mine waters, hydrodynamic situation, groundwater, coefficient of filtration, flooding of the territory.

\section{кологічні ризики т оцінк гідродин мічної ситу ції н шा $\mathbf{x т}$ х онецької т уг нської обл стей кр їни}

. . лицький, . . рм ков, . . уньов , . . угл к

ержсвн екологічн к демія післядіпломної освіти т упр вління, иїв, e-mail: Oksanalunova@gmail.com

нот ція. уч сні екологічні ризики т з грози стосуються нег тивного впливу нтропогенних т природних чинників н екосистеми, техногенні - нег тивного впливу промислових т потенційно небезпечних об'єктів, з бруднення джерел питної води, сільськогоспод рських земель, тмосферного повітря, вплив геологічного середовищ т н др н безпеку життєдіяльності н визн чених територіях. угільні підприємств є одним із об'єктів підвищеної екологічної небезпеки т критичної інфр структури. ьогодні екологічну безпеку н ході кр їни треб розгляд ти в тісному зв'язку з еколого-техногенними з гроз ми, що пов'яз ні з бойовими діями н цих територіях. втори здійснили н ліз н укових досліджень мінулих років т н д ли оцінку екологічних ризиків н територіях вуглевидобувних підприємств в суч сних умов х вр хув вши структурно-геологічні, геофільтр ційні т гірничо-геологічні п р метри, що є х р ктерними для онецької т уг нської обл стей кр їни. ст тті розглянуті території розміщення ш хт онецької т уг нської обл стей як зон підвищеної екологічної небезпеки. изн чено н явні екологічні з грози т ризики, н д но рекоменд ції щодо їх мініміз ції у р зі виникнення техногенноекологічних к т строф. кл дено рівняння розр хунку коефіцієнт фільтр ції у гірських пород х, про н лізов но гірничотехнічні п р метри вугільних ш хт. ок з но, що одним із н йбільш ймовірних ф кторів переходу території в зону н дзвич йної ситу ції регіон льного м сшт бу є виникнення ре льної з грози життю великої кількості людей в умов х м сового з топлення ш хт через припинення енергопост ч ння водовідливних т вентиляційних комплексів. кож в ст тті 
н уково обгрунтов но з безпечення прийнятного рівня екологічної безпеки скл дових н вколишнього природного середовищ (водного середовищ ) для н селення, які мешк ють в меж х гірничо-міських гломер цій з ур хув нням впливу н довкілля нег тивних ф ктороформуючих чинників, т кож прогнозув ння гідродин мічної ситу ції.

лючові слов : екологічн безпек, з грози т ризики, ш хтні води, гідродин мічн ситу ція, грунтові води, коефіцієнт фільтр иії, підтоплення території.

Introduction. Coal enterprises are one of the critical infrastructure objects (CIO) and high ecological danger objects and located both in the controlled and temporarily occupied territory.

It should be noted that on a controlled territory local authorities have the opportunity to monitor the state of the environment and control the development of events associated with the operation of these objects, which in turn enables the taking of measures to prevent emergencies, and in case of occurrence of such situations, to quickly locate and eliminate them. At the same time, central executive authorities and local self-government bodies do not known the state of the CIO located in the temporarily occupied territories of Donetsk and Luhansk regions. Due to this, the situation regarding their further safe functioning is not predictable.

Because of the hostilities, the threat of damage to such objects is quite large. Therefore, in case of an accident, the localization and elimination of the consequences of such a situation may be complicated due to the inability to access the places of damage. As an example, the mines of the Central region of Donbas.

Materials and methods. The analysis of the filtration model of mines flooding is considered with the scheme of the critical level of flooding of the produced space and the calculation of the filling factor $\left(\mathrm{K}_{\mathrm{f}}\right)$. Due to the active development in the zone of influence of coal-mining works of technogenic fracture, the aquifers, which water the mines, are dispersed, form three-dimensional geofiltration fields with a complex structure. As a result, each separate mine during flooding creates its own geofiltration field and the local water balance of the auto-rehabilitation rise of the groundwater level to natural (retro-historical) markings.

Autoreboiling mode of raising the levels in the process of flooding the mine from its maximum depth to the zone of regional permeability is ensured due to a significant excess of the area of depression over the generalized size ("large well") of mining production in the plan. In this regard, the structure of the graphoanalytic dependencies of the time tracking of the rise of levels during flooding of the mines (for example, the Gorlivka-Yenakiyevo mining and city agglomeration of the Donbas, the Central District of Donbas) mainly reflects the influence of the hydrodynamic potential of the depression reservoir outside the generalized drainage path of mining operations (Shestopalov V., 1991).

The authors carried out an analysis of scientific researches of the last years and tried to assess the ecological and geological risks in the territories of coal mining enterprises in the present conditions taking into account structural geological, geofiltration and mining-geological parameters that are characteristic of the Gorlivka-Yenakiyevo mining and city agglomeration (Sadovenko I., 1999).

It should be noted that the problems of the environmental consequences of military operations, attention was paid only relatively recently. Internationally, the environmental impact of conflicts in the former Yugoslavia, Afghanistan and the Middle East, conducted by the United Nations Environment Program (UNEP), is well known internationally. In 2006, the OSCE and UNEP assessed the spread of grass fires in NagornoKarabakh, and in 2008, the environmental consequences of the military conflict in Georgia. Today, various intergovernmental and nongovernmental organizations are taking part in assessing the environmental impact of hostilities in Syria and Iraq.

All organizations that prior to the conflict gathered information on the state of the environment in the Donetsk and Luhansk regions, suffered violations in their work, most of them lost their equipment, technical, material and transportation support, archives and documentation. The volume of reporting to the state statistics bodies has been reduced. At the same time, from the beginning of 2015, the Ministry of Ecology and Natural Resources of Ukraine, on the basis of available information, is preparing monthly informational and analytical certificates on the state of the environment in eastern Ukraine. Information on the humanitarian situation in settlements, as well as cases of violations of water, gas and electricity is contained in the daily summary data of the Information and Analytical Center of the National Security and Defense Council of Ukraine. An analysis of the situation in the conflict zone in the east of Ukraine is carried out for a limited set of sources (Rudko G., 2016).

Today, on parts of the territory environmental monitoring is not carried out, there is no reliable information about the nature of enterprise damage, the secrecy regime is in place, 
and the work of the State Environmental Inspectorates in the Donetsk and Luhansk regions is complicated. But in 2017, at the request of the Ministry of Ecology and Natural Resources of Ukraine, the OSCE Project Co-ordinator in Ukraine conducted a project "Determination of damage to the environment in eastern Ukraine", whose tasks were to conduct an analysis of the environmental impact of the conflict and to prepare recommendations for the prospective recovery of the region. The project was supported by the Government of Canada and Austria (Denisov N., 2017).

The main body. The flooding of mines, and the subsequent occurrence of areas flooded areas, is the main thing that will occur as a result of nonpower and damage to the equipment of enterprises of the coal mining industry, as well as one of the main causes of potential pollution of underground and surface water when they contact with mine waters. A particular threat is flooding of mines used

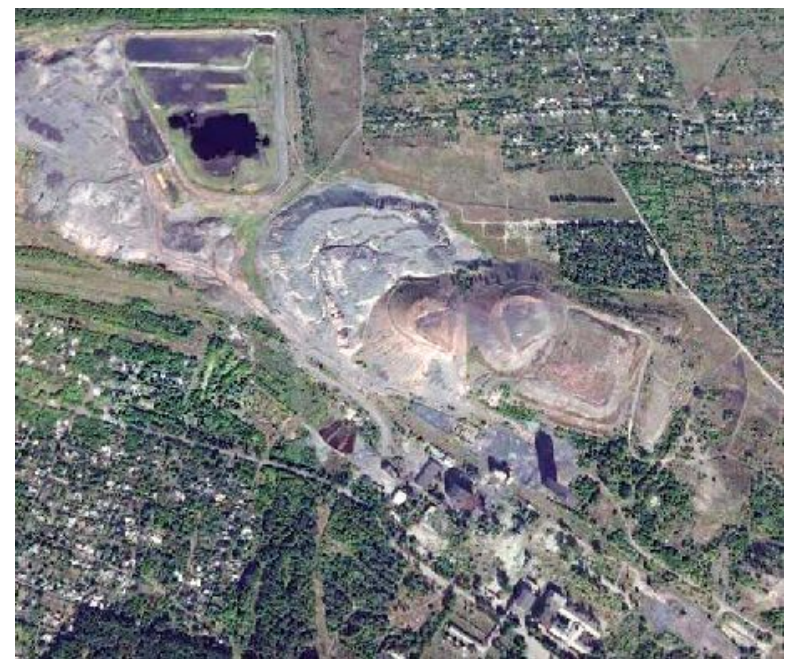

Fig. 1. Mine "Oleksandr-Zakhid"

As a result, buildings and structures of $\mathrm{CIO}$, such as water supply networks, underground gas pipelines, sewage systems and water supply systems, may be damaged. In addition, flooding of the

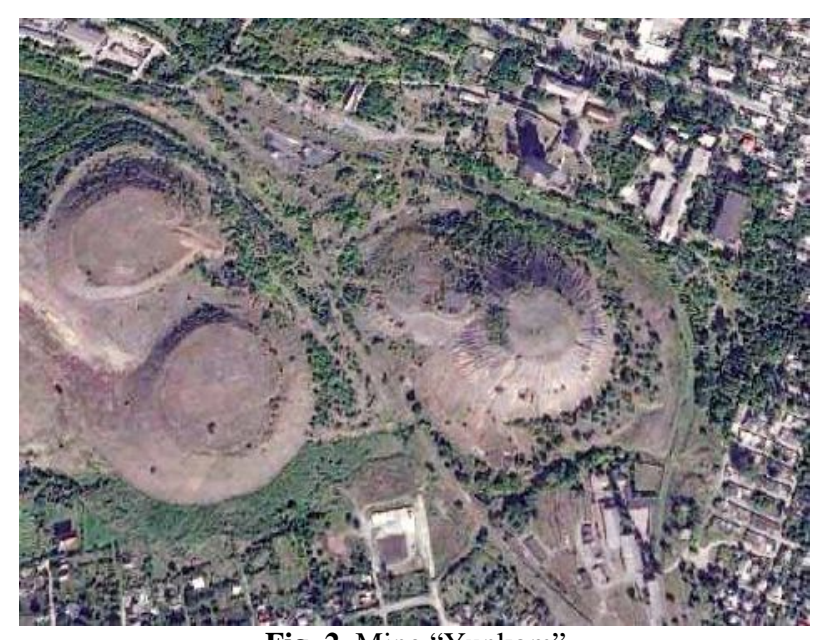

Fig. 2. Mine "Yunkom" as waste storage facilities. Such a danger, first of all, exists for the mines "Oleksandr-Zakhid", "Vuglegirska" and Kalinina in Gorlivka, Donetsk region. Radiation pollution of groundwater can cause flooding of the mine "Yunyy Comunar", where an underground nuclear explosion (object "Klivazh") was carried out in 1979 as part of the experiment to reduce the tension in the rock massif to improve the safety of the development of the coal seams of the Smolyanov's world $\left(\mathrm{C}_{2}{ }^{3}\right)$.It should be emphasized that in stable conditions and at the fulfillment of technological requirements for conservation, the risk of radioactive contamination beyond the boundaries of the Mining System "Yunyy Comunar - Klivaz" is practically absent, but with destabilization of the system and the absence of additional measures, it is possible to destroy this facility with the release of radioactive contaminated mine water in underground aquifers (up to $300 \mathrm{~m}^{3}$ /hour) (Rudko G., 2016).

Mine "Oleksandr-Zakhid" located in Gorlivka, Donetsk region on temporarily occupied territory. Since 2001, it is in the process of liquidation. The depth of development is 450 $\mathrm{m}$, the water intake is $220 \mathrm{~m}^{3} /$ hour.The discharge of mine water is carried out in the basin of the rivers Poklonska - Sadky - Krynka - Azov Sea.

Ecological threats: after the accident in 1989, the mine was transferred to a conservation mode, and since 2001 it has been transferred to the drainage regime under the project of liquidation. In 2017, the pumping of water on the $250 \mathrm{~m}$ horizon was stopped. Subsequent largescale flooding of the mine may lead to flooding of surrounding areas, affect the level of groundwater, cause soil subsidence (Bondar O., 2017, Lysychenko G., 2014)

mine will lead to pollution of underground and surface water by iron, chlorides, sulfates, other mineral salts and heavy metals.

Mine "Yunkom" located in Yenakievo, Donetsk region on temporarily occupied territory. Since 2001, it is in the process of liquidation. The depth of development is $936 \mathrm{~m}$, the water intake is $420 \mathrm{~m}^{3} /$ hour.The discharge of mine water is carried out in the basin of the rivers Millionna Bulavinka.

Ecological threats: After the discontinuation of coal mining in 2001, it was transferred to the drainage regime under the project of liquidation (flooded to the level absolute mark $-735 \mathrm{~m}$ ). Flooding of mining productions can lead to the accumulation of radionuclides in groundwater with the possible hydraulic displacement of them on the surface or in the flow of groundwater. (Bondar O., 2017). 
Environmental threats of location of the mine also include flooding of the surface, contamination of aquifers by mine water with high mineralization, methane gas output to the surface and its entry into the building and facilities, forming within the boundaries of the Gorlivka-Yenakiyevo industrial zone a dangerous man-made hydrogeofiltration system, it unites hydraulically connected mines of the region.

The leading methodological position is to determine the rate of lifting of groundwater levels to dangerous depths and the time of flooding of the mine as the main integral parameters for the probable forecasting of environmental impacts and the justification of effective engineering protection measures (Hydrogeology, 1971).

On the basis of the calculated difference of headings, in accordance with the position of the mirror of underground water carbon and hypsometry of the earth's surface, the possible yield of mine water to the surface of the earth at the site is assessed in the case of full flooding of mine productions. The equation of the calculation of the filtration coefficient in the rocks is made, the mining and technical parameters of the coal mines of the northern and southern wings of the central region of the Donbas (main anticline) are analyzed, flood levels of mine productions of the mines of the region are recorded, which testify to the formation of a complex man-caused geofiltration system in the zone of impact of mine dewatering, within which the following processes prevail:

- flooding of mining productions and watering of the adjoining massif of rocks with the rise of groundwater levels and reduction of their depression;

- additional shifts and sinking of rocks;

- change of the ways of migration of explosive and toxic gases (methane, radon, etc.), including towards existing mines, tectonic zones, underground spaces and reliefs;

- the dispersal of the migration of mineral waters of the deep horizons within the mine fields with their subsequent inflow into the local underground and surface runoff.

In order to take into account the influence of the basic balance parameters of mining operations (Babushkin V., 1972) (the cross-section of mine workings $F_{w, t}$ and active porosity or lack of water saturation), the following modification of the dependence of the Dyupui radial flow, which takes into account the time changes of the influx, $Q_{\amalg, t}$, . on the speed of lifting levels, $\mathrm{ds}_{\mathrm{t}} / \mathrm{dt}$ is used:

$$
\mathrm{Q}_{\mathrm{\omega}, \mathrm{t}} \approx \mathrm{F}_{\mathrm{\omega}, \mathrm{t}} \times \mu^{\mathrm{ds}} / \mathrm{dt} \approx \frac{2 \pi \mathrm{km} \mathrm{s}_{\mathrm{t}}}{\ln \mathrm{R} / \mathrm{r}_{\mathrm{m}}},
$$

where, $Q_{w, t}-$ water flow to the mine at time $t$ when the groundwater level decreases $S_{t} \mathrm{~m}^{3} /$ day; $F_{\mathrm{w}, \mathrm{t}}-$ free section of mine productions and the zone of artificial fracturing of broken rocks on the horizontal markings corresponding to $\mathrm{S}_{\mathrm{t}}, \mathrm{m}^{2} ; \mathrm{R}$ - the radius of depression of groundwater, $\mathrm{m} ; \mathrm{r}_{\mathrm{w}}$ - conditional radius of the planned contour of mining productions and zone of breakage (artificial fracturing), $\mathrm{m}$; - km - permeability of coal-rocks in natural or slightly degraded state, $\mathrm{m}^{2} /$ day;

- $\mu$ - the average value of active porosity (lack of water saturation) of coal-bearing rocks in the recovery zone of groundwater levels (in units).

The natural hydrodynamic situation of the Central district of Donbas is disturbed as a result of coal mining. The bottom depth of the mining works is within the limits of $740-1160 \mathrm{~m}$ and only on separate mines ("Oleksandr-Zakhid", "Pivdenna") 360-450 m.

Two thirds of the mining area has already been tampered with mining operations. The amount of water inflows in the mines of the region about $150-300 \mathrm{~m}^{3} /$ hour, and only at the mine "Chervonyy Zhovten", the mining of which crosses the river Bulavin, reaches $820-890 \mathrm{~m}^{3} /$ hour (Sadovenko I., 1999). Modules of mine water jets on $1 \mathrm{~km}^{2}$ of the mine shafts range from $2.9-25.31 / \mathrm{s}^{*} \mathrm{~km}^{2}$.

The most powerful bundles of dranaige rocks are fixed between the coal seams $\mathrm{h}_{1}, \mathrm{~h}_{3}, \mathrm{~h}_{10} \mathrm{i} \mathrm{h}_{11}, \mathrm{k}_{7}$, $\mathrm{k}_{7}{ }^{1 \mathrm{~B}}, \mathrm{k}_{5}{ }^{1}-\mathrm{k}_{7}{ }^{1 \mathrm{~B}}, \mathrm{l}_{1}, \mathrm{l}_{3}-\mathrm{l}_{5}, \mathrm{~m}_{5}{ }^{1}-\mathrm{m}_{4}{ }^{4}$, also in the zone of seams $\mathrm{h}_{4}-\mathrm{h}_{5}, \mathrm{k}_{1}-\mathrm{k}_{3}, \mathrm{~m}_{2}-\mathrm{m}_{3}, \mathrm{~m}_{6}{ }^{2}$.

According to some estimates, during the conflict, the total annual drainage in the Donbas decreased from 800 to $400-450$ million cubic meters (Ermakov V., 2017). With the preservation of this trend in a few years, part of the mine water will begin to fall into the underground aquifers, mixing with groundwater.

In the thickness of the carbon there are about 100 layers of sandstones, which form dispersed, almost independent pressure aquifers, sustained in length and constant power. The zones of the supply of underground waters of the regional cracked zone of carbon in the natural and weakly disturbed conditions are confined to the watersheds, are discharged into the valleys of the nearest rivers and beams. In the greater part of the territory, due to the hydrogeological openness of carbon and the active technogenic cracking of rocks, precipitation infiltration takes on the nature of infiltration. In the areas of river crevices mining by means of underground and surface waters a close hydraulic connection is established.

The result of the complex influence of manmade factors (increased infiltration of mineralized mine waters, geochemical contamination of landscapes, violation of regional watercourses, etc.) 
became almost complete replacement of fresh (up to $\left.1.0-1.5 \mathrm{~g} / \mathrm{dm}^{3}\right)$ and weakly mineralized $(1.5-3,0$ $\mathrm{g} / \mathrm{dm}^{3}$ ) water for water with mineralization 3.0-5.0 $\mathrm{g} / \mathrm{dm}^{3}$ at $70 \%$ of the investigated areas. In modern conditions, due to the sharp difference in the permeability and volume of infiltration feed of cover and coal deposits in the limits of the Gorlivka-Yenakiyevo mining and city agglomeration of the Donbas, the Central District of Donbas, two tiered structure of the hydrogeofiltration flow was formed. It should be construed that flooding of mines with subsequent raising of groundwater level and decreasing depression will increase the depth of groundwater supply, flood and flood processes, as well as water saturation and decrease of the strength of lower horizons of rocks with the manifestation of high- gradient sediments and breeds of continuity of rocks will increase. According to the results of modeling, on the $50 \%$ of the area of the GorlivkaYenakiyevo mining and city agglomeration of the Donbas, the forecast depth of groundwater levels of the coal-bearing horizon is $20.0 \mathrm{~m}$ or less, as a result of which this area is capable of local flooding of hot spots, development available and formation of new centers of pollution of groundwater (Temporary methodical recommendations, 2001).

Almost all of the mines in the GorlivkaYenakiyevo mining and city agglomeration of the Donbas, located on the Southern and Northern wings of the Main Anticline, are hydraulically interconnected in the range of depths of 230-1080 m (Fig. 3 and 4).

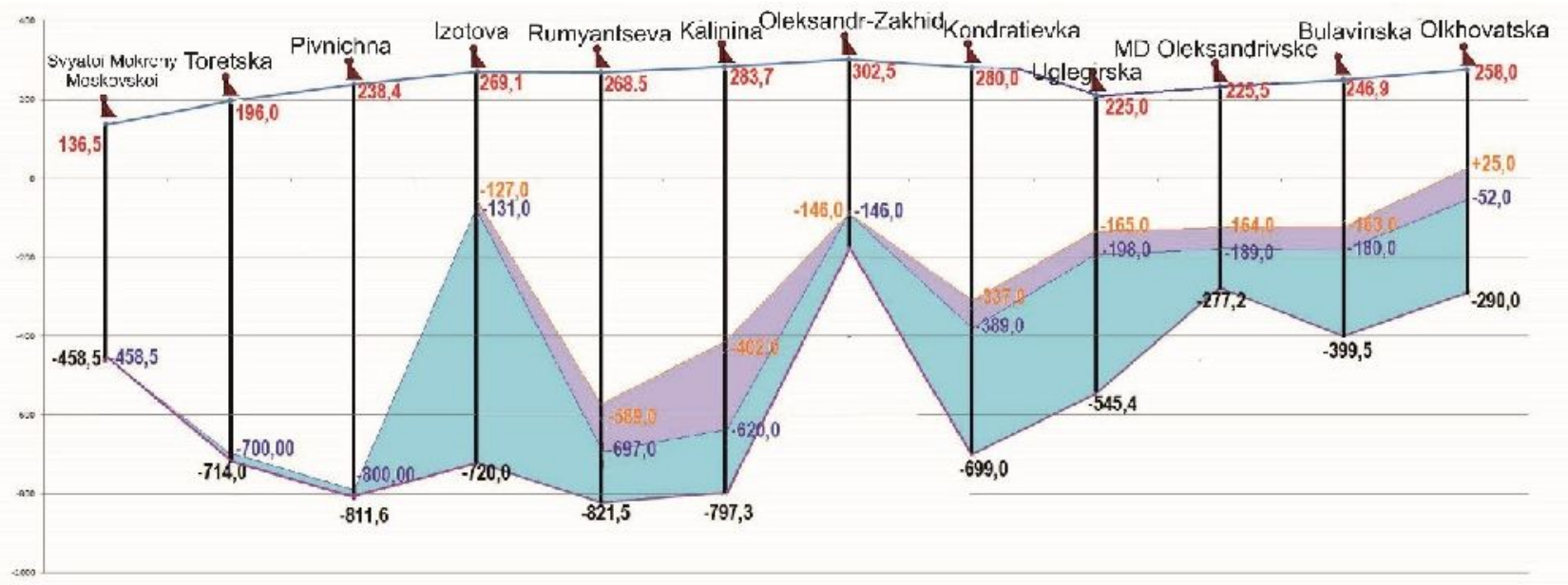

Fig. 3.Schematic section of the northern wing of the central region of Donbas (main anticline) on 01.06.2018

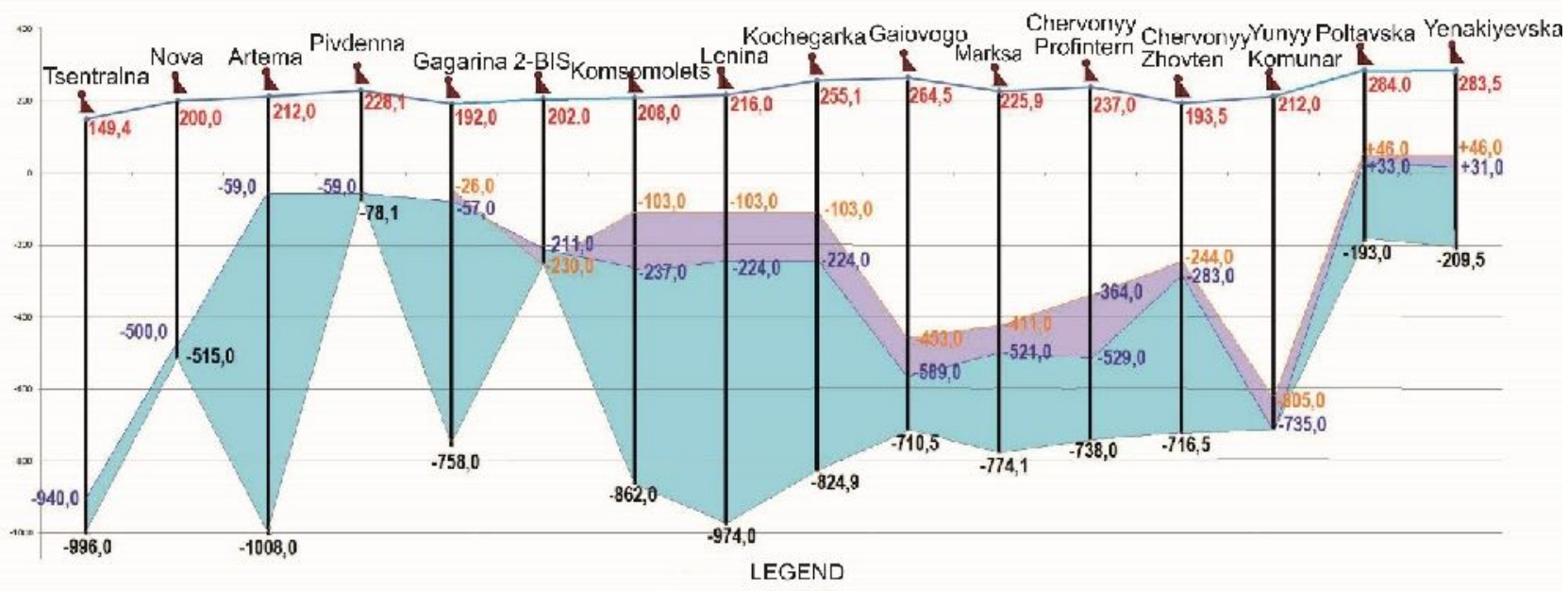

\footnotetext{
192,0 Absolute markings of the earth's surface of mine fields, m

$26,01.258,0$ Absolute markings of levels of flooding of mining productions, $m$

$-996,0$ The lower horizon of mining praductions
}

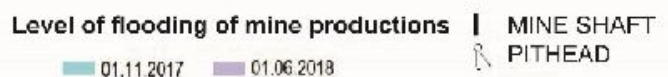

Fig. 4.Schematic section of the southern wing of the central region of Donbas (main anticline) on 01.06.2018

The analysis of the structural and geological structure and hydrogeological conditions of the mines of the Central District of Donbas has shown that they, in conjunction with the technological geological system "mine-geological environment" form a single hydraulically-geofiltration system 
with a high level of technogenic vulnerability of groundwater.

According to the available data (Yermakov V., 2017), the total number of direct hydraulic faults in these mines is about 14, and the approximate mining (for the standard reduction of intermontane shafts) - up to 10 zones with a total length of $\sim 1.5-2.0 \mathrm{~km}$. The distribution of abnormal mines in practically all depths (0.2-0.9 $\mathrm{km}$ ), in our opinion, can lead to activation of hydrogeomechanical deformations of the rock mass as a result of decreasing the rock strength through full or partial flooding of workings, as well as the formation of additional ways of accelerating migration of pollutants, explosive and toxic gases.

In the case of partial or full flooding of mines in the Gorlivka-Yenakiyevo mining and

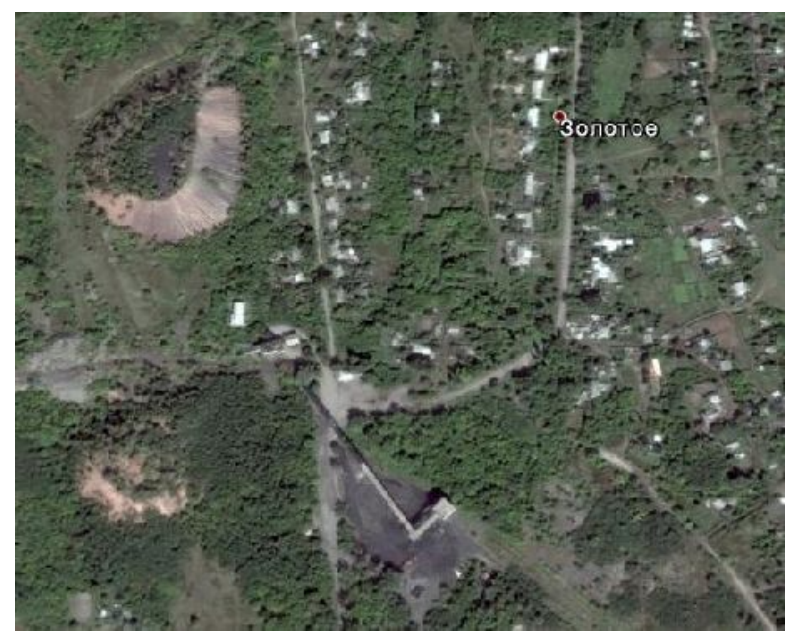

Fig.5 Mine "Zolote"

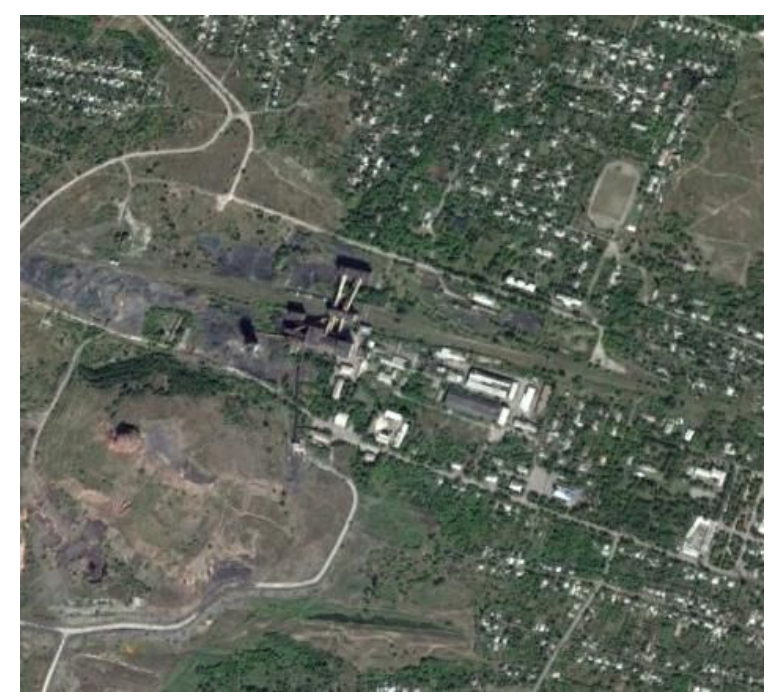

Fig. 6 Mine "Pervomayska" city agglomeration of the Donbas, without the prior application of engineering and protective and environmental measures, damage to the waterproofing of waste storage facilities, catastrophic contamination in mining operations, groundwater horizons and surface water streams may occur. Violation of the current equilibrium state of the technological geological system an industrial source of pollution -the geological environment can lead to the creation of an emergency ecological situation in this region. Volynetske and Olkhovatska reservoirs are in the territory of the Donetsk region under the threat of pollution; and the flooding of the Torez-Snizhne group mines can lead to the pollution of the Grabiv reservoir. All of these reservoirs are reserve sources for economic use.

Mine "Zolote" is located in Zolote, Popasna district of the Lugansk region. Put into operation in 1943. The design capacity is 650 thousand tons of coal per year, actual - 300 thousand tons. The mine field is uncovered by three vertical trunks, 2 - up to the horizon of 600 $\mathrm{m}, 1$ - up to the horizon $865 \mathrm{~m}$ and the sloped shaft. For the June 1, 2018, the water flow in mining productions is $260 \mathrm{~m}^{3} /$ hour. The discharge of mine water is carried out in the basins of the rivers Kamyshuvakha and Siversky Donets.

Ecological threats: in case of flooding of mining productions of the mine "Zolote" (to the absolute mark of the supposed overflow of water $-163 \mathrm{~m})$, mine water will fall on the working mines "Carbonit" and "Girska", which may lead to the discharging of highly mineralized contaminated mine water in the reservoir and small rivers, with possible water pollution in the wells of individual water use and in large water intakes, which provide drinking water all the Pervomaysk-Stakhanovsk region. (Shmandiy V.,

Mine "Pervomayska" is located in Pervomaysk, Lugansk region, on the temporarily occupied territory. Since 2005 is in the process of liquidation. The depth of development was $720 \mathrm{~m}$, the water flow was $325 \mathrm{~m}^{3} /$ hour. Mining productions are flooded.

Ecological threats: due to the accident December 2, 2015, the mine "Pervomayska" began flooding (flooded level - absolute mark $156 \mathrm{~m})$. The volume of water flow is $360 \mathrm{~m}^{3} /$ hour. The speed of raising the water level in the vertical shaft of the mine "Pervomayska" is $0.2 \mathrm{~m} /$ day. The expected flow of mine water towards the operating mine "Zolote" (due to the mining productions of the mine "Rodina") will occur at an absolute value of $-162.6 \mathrm{~m}$. 
In case of reaching the overflow horizon (absolute marking $-162 \mathrm{~m}$ ) and the flow of water to the mine "Zolote", the total additional volume of water from the two mines "Pervomayska" and "Golubivska" will be about $1060 \mathrm{~m}^{3}$ /hour. In general, the volume of water flow at the mine "Zolote" will be about $1500 \mathrm{~m}^{3} /$ hour. It is also possible to flood the Stakhanov-Bryanka region, closed mines of the Kirov group.

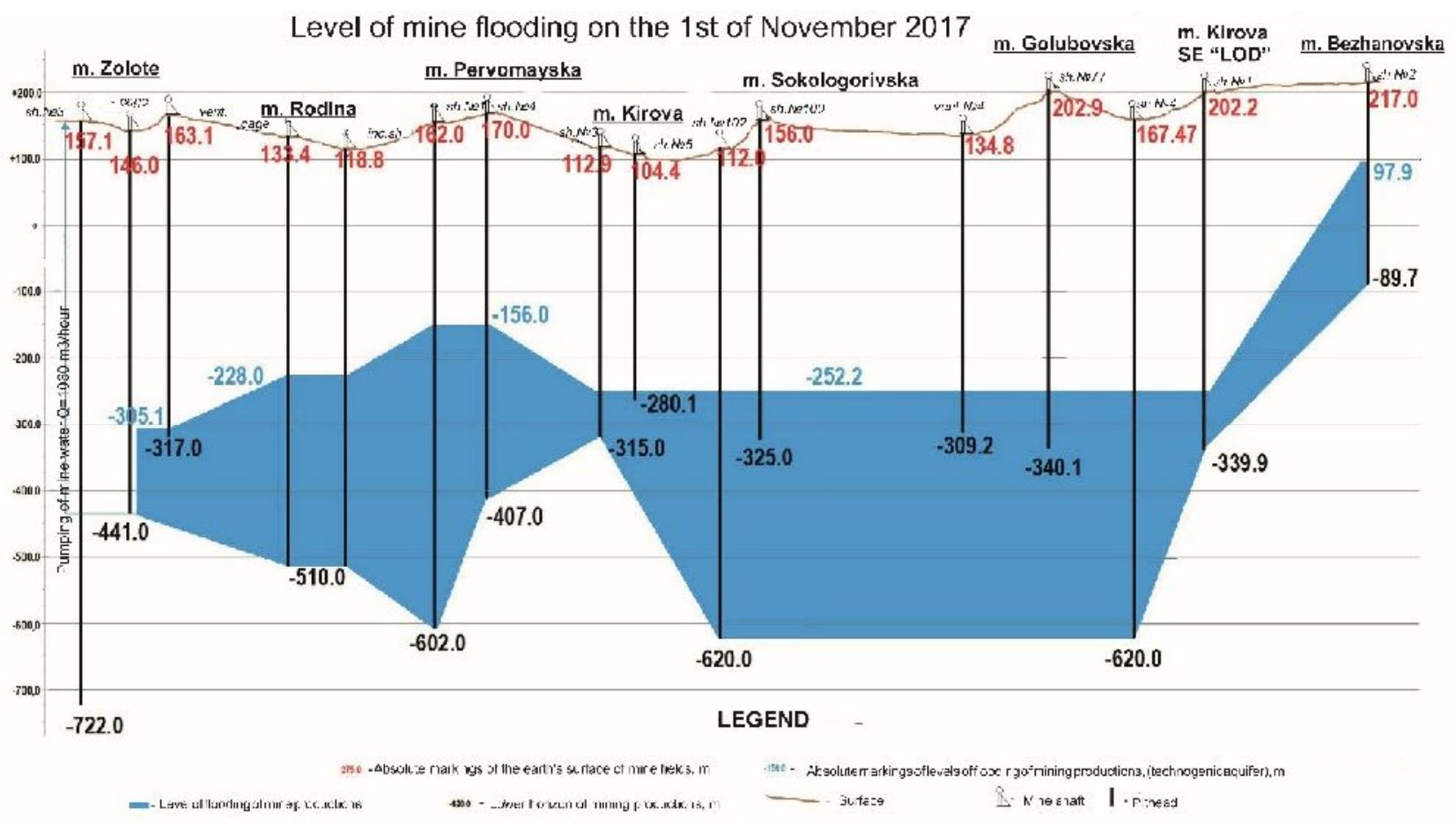

Fig. 7Schematic section of Pervomayska group of mines of Lugansk region

The operating mine "Zolote" and the mines "Pervomayska" and "Golubivska" are hydrogeologically interconnected. At the same time, mine waters flow from the mines "Golubivs'ka", "Pervomayska", in which, as a result of combat operations, the pumping of mine water was stopped, due to the productions of the mine "Rodina" on "Zolote", and then on the mine "Carbonit" and "Girska".

The flooding of the mining productions of the "Zolote" mine can lead to the following negative environmental consequences:

- discharges of highly mineralized contaminated mine water into the reservoir and small rivers, while the wells of individual water use and large water intakes can fail;

- changes in the physical and mechanical properties of the rocky rocks and the resulting additional shifts, and, consequently, the formation of cavities on the surface of the caverns in the underground space;

- collapse of the mouths of trunks, mining workings, having access to the surface and the adjoining earth's surface with possible flooding;

- occurrence of uncontrolled release of mine gases, in particular methane, on the surface;
- violation of the conditions for the normal functioning of mining towns and settlements, which at the time of closure of mines were already repeatedly forged by mining;

- activation of the deformation of the rock, due to their rinsing when flooding the mines, which can cause additional damage to buildings and structures.

Conclusions and recommendations for minimizing risks.

For the group of mines "Zolote", "Pervomayska”, “Golubivska”.

In order to minimize risks, it is essential to strengthen the drainage complex of the "Zolote" mine. The optimal solution is to build a group drainage at the mine "Zolote" with a capacity of $1366-1500 \mathrm{~m}^{3} /$ year.

It is also necessary to carry out:

- measures for the prevention of pollution and depletion of underground and surface waters;

- mechanical clearing and degassing of mine sewage;

- clearing underground drains;

- production control of the composition and properties of sewage, their influence on the state of surface waters; 
- radiological examination of the territory;

- prevention of spontaneous combustion of rock mass in dumps;

- measures to prevent the development of dangerous geological processes (karst, landslides, subsidence, flood, etc.);

- if possible, to resume pumping of mine water in the mines "Golubivska" and "Pervomayska".

For the mine "Oleksandr-Zakhid"

- it is necessary to monitor the migration processes of explosive and highly toxic gases and compounds;

- it is necessary to develop measures for the prevention of pollution and depletion of underground and surface waters, the development of dangerous geological processes (karst, landslides, subsidence, flooding, etc.);

- if possible, resume pumping of mine water into the mine.

\section{For the mine "Yunkom"}

- conduct a comprehensive radioecological survey of the mine "Yunkom" and its zone of influence in order to identify areas of accumulation, ways of distribution and migration of groundwater (with dangerous solutions present in them) that rise to the surface during uncontrolled flooding of the mine;

- to create a monitoring system on the level of raising and distribution of water supplies to adjacent mining and industrial objects, nonindustrial objects and the environment;

- on the basis of the evaluations carried out and according to the obtained data, to carry out the classification of the object "Klivazh" in accordance with the requirements of the regulatory framework in the field of radioactive waste management and radiation safety;

- taking into account the above and in order to prevent the contaminated water from entering the general water supply system, take urgent measures to ensure an adequate level of safety at the mine "Yunkom" and in the area of migration of polluted waters in the area of the mine location.

- development of measures to prevent pollution and depletion of underground and surface waters, development of dangerous geological processes (karst, landslides, subsidence of the surface, flooding, etc.).

Thus, one of the most probable factors of the transition of the territory of Donetsk and Lugansk regions to the state of emergency on a transboundary scale is the risk of massive uncontrolled flooding of the mines due to the cessation of the supply of drainage and ventilation systems. The consequences of rising groundwater to the surface may be the flooding of large areas of adjacent cities and towns, subsidence of the earth's surface in built-up areas, pollution of surface and underground water intakes. In addition, there is a risk of methane migration to basements, ravines, gullies and basins, which will increase the risk of explosions and fires.

Given the impossibility of verifying and carrying out a comprehensive analysis of the hydrogeological state of the mines in the Donetsk and Luhansk regions of Ukraine due to their location on the uncontrolled territory by the Ukrainian authorities, we consider it expedient to work out the issue raised during the meeting of the Tripartite Contact Group in Minsk on the settlement of the situation in the Donbas for discussion with representatives of certain districts of the Donetsk region, where the mines are located, to take appropriate response and protection measures.

\section{References}

Babushkin V.D., 1972. Prognoz vodopritokov v gornyye vyrabotki i vodozabory podzemnykh vod v treshchinovatykh i zakarstovannykh porodakh [Forecast of water inflows into mine workings and water intakes of underground waters in fractured and karsted rocks]. V.D.Babushkin, Z.P.Lebedyanskaya, P.Z.Levi M.: Nedra, 1 175.

Bondar . Ulytsky ., Yermakov V., 2017. Zvit pro nadannya poslugy "Provedennya otsinky ta vyvchennya tekhnogennogo stanu Donetskoi ta Luganskoi oblastei $\mathrm{z}$ metoyu rozrobky recomendatsii shchodo pryrodno-resursnogo vidnovlennya na ekologichnykh zasadakh" [Report on the provision of the service "Assessment and study of the ecological and man-made state of Donetsk and Luhansk regions in order to develop recommendations on environmental rehabilitation on an ecological basis"'] Kyiv, 177 (in Ukrainian),

Denisov N. D.Averin, .Yushchuk, O.Ulytsky, P.Bystrov, S.Zibtsev, S.Chumachenko, Y.Nabyvanets, 2017. Otsinka ekologichnoi shkody ta priorytety vidnovlennya dovkillya na skhodi Ukrainy [Assessment of environmental damage and environmental recovery priorities in eastern Ukraine] Organization for Security and Co-operation in Europe, 88 (in Ukrainian).

Gidrogeologiya SSSR. Tom VI. Zatopleniye i otkachka shakht Donbassa. [Hydrogeology of the USSR. Volume VI. Flooding and pumping of mines in Donbas] - M.: Nedra, 1971. - 480

Lysychenko G., Zabulonov Y., Khmil G. (2008) Pryrodnyi tekhnogennyi ta ekologichnyi ryzyky: analiz, otsinka, upravlinnya [Natural man-made and environmental risks: analysis, evaluation, management] .: Joint-Stock Company «Vitol» (in Ukrainian), 544

Rudko G., Yakovlev . and other (2016) Ekologichna bezpeka vugilnykh rodovyshch [Ecological safety 
of coal deposits of Ukraine] monography, VVDBuk Rekm, Chernivtsi (in Ukrainian), 608

Sadovenko I., Razumniy Y.and other (1999) Zvit pro naukovo-doslidnu robotu "Obosnovat gidrologicheskiy rezhim i tekhnologicheskiye resheniya po yego podderzhaniyu pri zakrytii ugolnykh shakht Tsentralnogo rayona Donbassa" [Report "To substantiate the hydrological regime and technological decisions on its maintenance at the closing of coal mines of the Central region of Donbas"], Dnepropetrovsk, 160

Shestopalov V.M., Ognyanyk N.S., Drobnokhod N.N. and other/ Vodoobmen $\mathrm{v}$ gidrogeologicheskikh strukturakh Ukrainy: vodoobmen v narushennykh usloviyakh [Water exchange in hydrogeological structures of Ukraine: water exchange in disturbed conditions] - Institute of geological sciences. - Kiev: Nauk.dumka, 1991. - 528

Shmandiy V.M. and other (2013) Ekologichna bezpeka: pidruchnyk [Ecological safety: textbook]-Herson: Oldi plyus, 366

Vremennyye metodicheskiye rekomendatsii. Po metodam predvaritelnoy otsenki izmeneniy gidrogeologicheskoy obstanovki i optimizatsii nablyudatelnoy seti $\mathrm{v}$ sisteme monitoringa podzemnykh vod $\mathrm{v}$ Donbasse pri zakrytii shakht.[Temporary methodological recommendations. On methods of preliminary assessment of changes in the hydrogeological situation and optimization of the observation network in the groundwater monitoring system in Donbas when mines are closed. Dnepropetrovsk: TO UkrGGRI, 2001. - 67 p.] Dnepropetrovsk: DO UkrGGRI, 2001. - 67

Yermakov V., Ulytsky ., Bondar . (2017) and other. Zvit pro naukovo-doslidnu robotu "Monitoryng vykonannya pryrodookhoronnykh robit ta ekolohichnogo stanu pryrodnogo dovkillya diyuchykh ta likvidovanykh vugilnykh pidpryyemstv, rozroblennya propozytsiy shchodo yogo polipshennya [Report "Monitoring the performance of environmental works and ecological state of the environment of operating and liquidated coal enterprises, developing proposals for its improvement"], Kyiv, 97 